\title{
MANAJEMEN STRATEGIS KEPALA SEKOLAH DALAM UPAYA MENARIK MINAT CALON PESERTA DIDIK DI SMPIT AR-RIDHO PALEMBANG
}

\author{
${ }^{1}$ Herni Irmayani dan ${ }^{2}$ Dessy Wardiah \\ ${ }^{1}$ Peneliti dan Praktisi Pendidikan Kota Palembang \\ ${ }^{2}$ Dosen Program Pascasarjana Universitas PGRI Palembang \\ e-mail: herniirmayani88@gmail.com
}

\begin{abstract}
This research aimed at identifying the strategic management of the principal in attracting prospective learners in Islamic Intergrity Secondary School Ar-Ridho Palembang, how the implementation in attracting prospective students in Islamic Intergrity Secondary School ArRidho Palembang, Evaluation and follow-up of principal strategy in attracting candidate students in Islamic Intergrity Secondary School Ar-Ridho Palembang, This research was qualitative. The subjects of this research were principal, committee of Students' Admission and some parents. The instruments were interviews and observations. Data analysis used Miles and Huberman model. The result of the research was that during the two years of Students' Admission implementation, the headmaster and Students' Admission committee experienced difficulties in cooperation with the foundation, especially on Students' Admission funds. Technically all the preparations include the formation of the committee, the determination of activity, budget, schedule, determining the location of the activity, the target of the activity, and the determination of the material in the activity already programmed. The media used to remember the minimal cost is limited based information from parents whose children are learning in Secondary School Ar-Ridho Palembang Ar-Ridho. Evaluation was done in the closing meeting of Students' Admission, the things are evaluated include the match between the number of learners with the target capacity, the weaknesses was on the method or committee.
\end{abstract}

Keywords: Strategic Management, Headmaster, Students' Interest, SDIT Ar-Ridho

\section{PENDAHULUAN}

Setiap lembaga pendidikan memiliki program unggulan dalam menarik minat masyarakat. Persaingan dalam rangka "menjemput bola" para calon siswa sekolah dapat dirasakan sekali bagi sekolah swasta. Betapa tidak dengan nilai nominal yang ditawarkan yang tergolong tidak sedikit, para orang tua akan berlaku selektif.

Sah-sah saja promosi dilakukan melalui berbagai media dan cara. Dari mulai iklan dari mulut ke mulut para orang tua sampai pada iklan layanan eletronik dengan web sekolah yang dapat diakses setiap orang melalui internet. Perbedaan yang dirasakan antara sekolah swasta dan negeri adalah bahwa setiap tahunnya sekolah swasta berusaha menarik minat siswa dengan program kegiatan yang beragam dan menampilkan program unggulan. Sementara sekolah negeri favorit katakanlah lebih cenderung memilih menunggu dan mempersiapkan kelas dengan daya tampung maksimal. Tak jarang setiap tahun mereka akan menolak calon peserta didik dengan alasan jumlah siswa sudah mencukupi kuota tiap kelas atau rombel. Bagi 
sekolah swasta yang juga tergolong sudah memiliki nama/bonafit seperti SMP Paramount, SMPT Al-Furqon, SIT Al-Azhar, SMPIT Bina Ilmi, tak jarang mereka sudah menutup penerimaan siswa baru jauh sebelum pelaksanaan tahun ajaran baru tiba.walau dengan nominal yang cukup fantastis, orang tua lebih memilih sekolah tersebut daripada sekolah negeri yang dekat dengan rumah atau sekolah swasta lain. Banyak faktor yang membuat para orang tua memilih memasukkan anak mereka ke sekolah "mahal", salah satunya mereka menilai bahwa anak-anak dapat menerima pengetahuan agama lebih dibandingkan dengan sekolah biasa.

Lalu bagaimana dengan sekolah swasta bernuansa islam terpadu yang berada pada wilayah kecamatan yang sama? Apakah akan mendapatkan siswa dengan jumlah yang diinginkan atau justru gulung tikar karena tidak mendapat siswa. Bagaiamana strategi kepala sekolah dalam menghadapi tantangan persaingan sekolah seperti ini? Tentunya berbagai upaya yang dapat dilakukan sudah menjadi program tahunan yang dibuat sedemikian rupa bersama dalam rapat dewan yayasan dan dewan guru.

Salah satu sekolah swasta yang berada pada range yang sama dengan sekolah Paramaount adalah SMPIT Ar-Ridho Kota Palembang. Tergolong sekolah baru karena baru menerima tahun kedua siswa.
Beroperasionalnya sekolah ini pada tahun 2015-2016 dengan jumlah siswa 14 anak. Semuanya berada dikelas 7 sebanyak 10 siswa dan kelas 8 sebanyak 14 siswa. Jumlah seluruh siswa sebanyak 24. Kapasitas kelas yang cukup besar dengan daya tampung 32 siswa. Berlokasi yang sangat strategis dan biaya yang relative murah. Apa yang menyebabkan sekolah ini hanya mendapat siswa kurang dari separuh daya tampung. Sebetulnya menjadi sarana yang cukup strategis dan memiliki daya saing yang tinggi. Adapun informasi yang penulis dapat dari lapangan, bahwa sekolah ini memiliki sarana yang cukup baik, seperti lokasi yang strategis dekat dengan lingkungan masyarakat, gedung milik sendiri dengan kapasitas 3 lantai, setiap lantai memiliki 4 ruang kelas dengan kapasitas 32 siswa. Memiliki ruang labor computer, perpustakaan, ruang ibadah, ruang kantor, dan ruang istirahat bagi siswa. Sekolah Islam terpadu Ar-Ridho ini lebih beorientasi kepada Full day school. Siswa belajar dari pukul 07.00 sampai dengan pukul 15.30 (ba'da Ashar). (informasi dari hasil pengamatan dan wawancara langsung penulis dengan kepala sekolah pada tanggal 15 Desember 2016).

Berdasarkan hasil pengamatan penulis, sekolah hanya mendapatkan siswa sedikit. Dari tahun pertama berjumlah 14 siswa maka tahun kedua mengalami penurunan hanya menerima 10 siswa. Berdasarkan temuan 
masalah ini, penulis berupaya mencoba untuk melihat apa sebenarnya strategi kepala sekolah dalam rangka menarik minat calon peserta didik di SMPIT Ar-Ridho Palembang Apa saja kendala dan bagaimana evaluasi yang dilakukan setiap tahun terhadap kegiatan PPDB siswa.

\section{MANAJEMEN STRATEGIS}

Strategis berasal dari bahasa Yunani "stratogos" yang artinyanya ilmu para jenderal untuk memenangkan suatu pertempuran dengan menggunakan sumber daya yang terbatas. Sedangkan manajemen menurut bahasa Perancis Kuno "management" yang berarti seni yang melaksanakan dan mengatur. Menurut Kristiawan dkk (2017) Manajemen berasal dari bahasa latin dari kata "manus" yang artinya "tangan" dan "agere" yang berarti “ melakukan". Kata-kata ini digabung menjadi "managere" yang bermakna menangani sesuatu, mengatur, membuat sesuatu menjadi seperti apa yang diinginkan dengan mendayagunakan seluruh sumber daya yang ada. Strategis sebagai "penciptaan posisi unik dan berharga yang didapatkan dengan melakukan serangkaian aktivitas" (Porter, 1996).

DefInisi manajemen strategis dalam ilmu manajemen memiliki cakupan yang luas, dan tidak ada suatu pengertian yang dianggap baku. Itulah sebabnya defenisi manajemen
Defenisi managemen strategis dalam ilmu manajemen memiliki cakupan yang luas, dan tidak ada suatu pengertian yang dianggap baku. Itulah sebabnya defenisi manajemen strategi berkembang tergantung pemahaman atau penafsiran seseorang. Meskipun demikian dari berbagai defenisi yang diberikan oleh para manstrategi berkembang tergantung pemahaman atau penafsiran seseorang. Meskipun demikian dari berbagai defenisi yang diberikan oleh para pakar manajemen dapat ditemukan suatu kesamaan pola pikir, bahwa manajemen strategi adalah suatu seni dan ilmu dari suatu pembuatan (formulating), penerapan (implementing) dan evaluasi (evaluating) keputusan-keputusan strategis antr fungsi-fungsi yang memungkinkan sebuah organisasi mencapai tujuan-tujuan masa datang (Wahyudi, 1996). Manajemen strategis adalah seni dan ilmu penyusunan, penerapan, dan pengevaluasian keputusan-keputusan lintas, manajemen strategis berfokus pada proses penetapan tujuan organisasi, pengembangan kebijakan dan perencanaan untuk mencapai sasaran, serta mengalokasikan sumber daya untuk menerapkan kebijakan dan merencanakan pencapaian tujuan organisasi. Manajemen strategis mengkombinasikan aktivitas-aktivitas dari berbagai bagian fungsional suatu bisnis untuk mencapai tujuan organisasi. Ada tiga tahapan dalam manajemen strategis, yaitu perumusan strategi, 
pelaksanaan strategi, dan evaluasi strategi (David, 2004).

Berdasarkan pengertian di atas, dapat disimpulkan bahwa managemen strategis adalah segala kegiatan yang diawali dari kegiatan melakukan penyusunan suatu program, melakukan penerapan program sampai pada pelaksanaan evaluasi program, baik jangka pendek maupun jangka panjang. Dalam bidang pendidikan, manajemen strategi dapat dikonversikan ke dalam satuan pendidikan, karena pendidikan juga merupakan kumpulan dari orang-orang yang tersistem dalam suatu kegiatan terorganisir dengan tujuan yang jelas berlandaskan pada visi dan misi pendidikan. Memiliki target pekerjaan jangka pendek, menengah dan jangka panjang.

Sekolah merupakan satuan pendidikan yang menyelenggarakan proses belajar mengajar mempunyai fungsi dan tujuan yang termuat didalam Undang-Undang Nomor 20 tahun 2003 pasal 3, tentang Sistem Pendidikan nasional, yaitu mengembangkan kemampuan dan membentuk watak serta peradaban bangsa yang bermartabat dalam rangka mencerdaskan kehidupan bangsa, yang bertujuan untuk mengembangkan potensi peserta didik agar menjadi manusia beriman dan bertaqwa kepada Tuhan Yang Maha Esa, berakhlak mulia, sehat, berilmu, cakap, kreatif, mandiri dan menjadi warga Negara demokratis serta bertanggung jawab. (Ahmad, Syarwani dalam Departemen Pendidikan Nasional RI, UU Republik Indonesia No. 20 tahun 2003, 2016). Strategi pelaksanaan kegiatan diarahkan pada target yang hendak dicapai, baik dalam jangka pendek maupun jangka panjang. Pemilihan strategi dilakukan dengan mempertimbangkan keadaan situasi dan kondisi yang terjadi saat ini dan yang telah diperkirakan untuk yang akan datang.Waktu dengan tujuan yang telah ditetapkan diperkirakan relevansinya sehingga penerapan strategi yang telah ditetapkan tidak mempersulit tercapainya tujuan organisasi.

Terdapat dimensi keputusan strategi mutlak dan perlu dikenali dan diperhitungkan, antara lain adalah:

a. Dimensi keterlibatan manajemen puncak yang menyangkut seluruh segi organisasi.

b. Dimensi alokasi dana, sarana dan prasarana, keputusan manajemen puncak tentang satuan kerja yang ditugaskan memainkan peranan yang strategic pada suatu moment tertentu menentukan alokasi dana, sarana dan prasarana dan tenaga yang mungkin melebihi apa yang dialokasikan pada satuan-satuan kerja yang lain.

c. Dimensi waktu keputusan strategic, Jangka waktu yang relative jauh ke depan apakah itu lima atau sepuluh tahun lebih itu menentukan target produk yang dapat dihasilkan. 
d. Dimensi orientasi masa depan, keputusan strategic yang didasarkan pada sikap proaktif dan antisipatif, manajemen akan lebih siap menghadapi tantangan perubahan yang akan terjadi dan tidak akan dihadapkan pada dihadapkan pada kepada situasi dadakan.

e. Konsekuensi isu strategis yang multifaset. Keputusan strategi biasanya menjangkau semua komponen atau unsur organisasi, baik dalam arti dana, sarana, prasarana, tenaga kerja maupun dalam arti satuansatuan kerja yang terdapat dalam organisasi seperti departemen, divisi, biro, bagian, seksi, direktorat dan lain sebagainya.

f. Dimensi lingkungan ekternal, tantangan yang dihadapi bukan hanya internal saja, akan tetapi dari luar organisasi sangat perpengaruh, seperti pengangguran, gaya hidup, geopolitik, peningkatan taraf hidup dan sebagainya (Siagian, 2012).

\section{PESERTA DIDIK}

Peserta didik adalah makhluk Allah yang terdiri dari aspek jasmani dan rohani yang belum tercaapi taraf kematangan, baik fisik, mental, intelektual, maupun psikologinya (Suharto, 2006). Oleh karena itu, ia senantiasa memerlukan bantuan, bimbingan dan arahan pendidik agar dapat mengembangkan potensinya secara optimal dan membimbingnya menuju kedewasaan. Potensi dasar yang dimiliki peserta didik, kiranya tidak akan berkembang secara maksimal tanpa melalui proses pendidikan. Adapun peserta didik dalam pendidikan islam ialah setiap manusia yang sepanjang hayatnya selalu berada dalam perkembangan (Aly Noer, H, 1999). Jadi, bukan hanya ank-anak yang sedang dalam pengasuhan dan pengasihan orangtuanya, bukan pula anak-anak dalam usia sekolah. Samsul Nizar dalam "Filsafat Pendidikan Islam: Pendekatan Historis, Teoritis dan Praktis" menyebutkan beberapa deskripsi mengenai hakikat peserta sebagai berikut.

a. Peserta didik bukan miniatur orang dewasa, tetapi ia memiliki dunianya sendiri. Hal ini perlu dipahami, agar perlakuan terhadap mereka dalam proses pendidikan tidak disamakan dengan pendidikan orang dewasa

b. Peserta didik adalah manusia yang memiliki perbedaan dalam tahap-tahap perkembangan dan pertumbuhannya. Pemahaman ini perlu diketahui agar aktivitas pendidikan islam dapat disesuaikan dengan tingkat pertumbuhan dan perkembangan yang umumnya dialami peserta didik

c. Peserta didik adalah manusia yang memiliki kebutuhan yang harus dipenuhi baik yang menyangkut kebutuhan jasmani atau rohani 
d. Peserta didik adalah makhluk Allah yang memiliki berbagai perbedaan individual (individual differentiations) baik yang disebabkan karena faktor bawaan maupun lingkungan tempat ia tinggal

e. Peserta didik merupakan makhluk yang terdiri dari dua unsur utama: jasmani dan ruhaniah. Unsur jasmani berkaitan dengan daya fisik yang dapat dkembangkan melalui proses pembiasaan dan latihan, sementara unsur ruhani berkaitan dengan daya akal dan daya rasa

f. Peserta didik adalah makhluk Allah yang telah dibekali berbagai potensi (fitrah) yang perlu dikembangkan secara terpadu (Toto Suharto. 2006: 124-125).

Berdasarkan beberapa pendapat di atas, peserta didik dapat dikatakan sebagai orang yang belum dewasa dan memiliki sejumlah potensi (kemampuan) dasar yang masih perlu dikembangkan. Masa akhir usia 12 tahun para pendidik harus tanggap bahwa peserta didik mulai ada tanda-tanda perubahan tubuh khususnya wanita yang diikuti dengan perubahan rohaninya karena permulaan puber pertama. Sedangkan masa puberitas yang sesungguhnya memasuki usia $14-21$ tahun, hal ini dapat dikatagorikan menjadi:

1. Masa pra pubertas: wanita $12-13$ tahun, laki-laki 13 - 14 tahun

2. Masa pubertas: wanita $13-18$ tahun, laki-laki 14 - 18 tahun
3. Masa adolesen: wanita $18-21$ tahun, laki-laki 19 - 23 tahun (Ahmadi dan Uhbiyati, 2001).

\section{METODE PENELITIAN}

Penelitian mengenai manajemen strategi kepala sekolah dalam upaya menarik minat calon peserta didik di SMPIT Ar-Ridho Kecamatan Kalidoni Kotamadya Palembang ini dilakukan dengan menggunakan penelitian kualitatif deskriptif. Penelitian deskriptif adalah penelitian yang bertujuan untuk mendeskripsikan atau mengambarkan fenomena-fenomena yang ada. Penelitian deskriptif tidak memberikan perlakuan, manipulasi atau pengubahan pada variabelvariabel bebas, tetapi mengambarkan suatu kondisi apa adanya.

Dalam penelitian ini, peneliti ingin menggambarkan bagaimana manajemen strategis kepala sekolah dalam upaya menarik minat calon peserta didik di SMPIT Ar-Ridho Kecamatan Kalidoni Kotamadya Palembang, karena itu penelitian deskriptif dianggap sangat tepat digunakan dalam penelitian ini. Penelitian ini termasuk penelitian kualitatif, yaitu penelitian yang dianalisis berdasarkan logika berpikir ilmiah. Penelitian ini dilakukan di SMPIT AR-RIDHO Kecamatan Kalidoni Kotamadya Palmbang, Waktu penelitian ini dilaksanakan pada Bulan Desember 2016. Adapun sumber data dari penelitian ini adalah 
Pengurus Yayasan Jannatul Firdaus, Kepala Sekolah, dan wakil kurikulum SMPIT ArRidho Palembang. Teknik pengumpulan data yang digunakan dalam penelitian ini adalah observasi, wawancara dan dokumentasi.

Observasi ialah pengamatan dan pencatatan yang sistematis terhadap gejalagejala yang diteliti (Usman dan Akbar, 1996). Dalam observasi penelitian ini, hal-hal yang menjadi perhatian penulis adalah bagaimana upaya kepala sekolah dalam rangka menarik minat calon peserta didik di SMPIT Ar-Ridho dan evaluasi tindak lanjut terhadap hasil PPDB siswa setiap tahunnya. Dokumentasi adalah data berupa catatan, buku-buku, transkip mengenai hal-hal yang diselidiki.

\section{HASIL PENELITIAN DAN PEMBAHASAN a. Deskripsi SMPIT Ar-Ridho}

Sekolah SMPIT Ar-Ridho terletak di Jalan Residen H Abdul Rozak Kecamatan Kalidoni Kotamadya Palembang. Lingkungan yang cukup strategis dijangkau dari lokasi sekolah dasar yang berada disekitar sekolah. ada disekitar sekolah. Sekolah-sekolah yang berada pada range sekolah SMPIT Ar-Ridho meliputi SDN 50, SDN 200, SDN, MI Mambaul Hidayah, SD ST. Qaverius, dan SD Muhammadyah serta SDIT Ar-Ridho. Lingkungan masyarakat yang cukup padat, berada di lingkungan Perumahan Tentara (Ajen) dan berbaur pula dengan lingkungan masyarakat RT 12 (Hasil observasi penulis, 15 Desember 2016).

Sekolah ini dibangun oleh seorang Penceramah Ibu Hj. Farida Silalahi pada tahun 2012. Pada awalnya sudah pernah beroperasi sekolah ini ditahun 2012-2013 tetapi hanya memiliki 3 siswa. Dengan pertimbangan siswa yang masih sedikit, maka pembelajaran dilaksanakan di gedung SDIT Ar-Ridho dilantai 4. Pada tahun 2013-2014 sekolah terpaksa ditutup sementara dikarenakan tingginya biaya operasional yang tidak sesuai dengan jumlah siswa, dan tidak memperoleh siswa dalam kegiatan PPDB, serta gedung yang akan ditempati masih belum rampung $50 \%$, siswa yang berjumlah 3 orangpun semuanya pindah sekolah. Dibuatlah surat yang ditujukan ke Kepala Diknas Kota Palembang, bahwa sekolah menutup sementara kegiatan pembelajaran di sekolah tersebut. (wawancara dengan Kepala Sekolah, tanggal 15 Desember 2016).

Pada tahun pelajaran 2015-2016 sekolah mulai beroperasional kembali dengan konsep dan fasilitas yang berbeda. Dibawah kepemimpinan Bapak Syukron Kasir, S.Pd.I dan Wakil Kurikulum Ibu Herni Irmayani, SH. Dan tim guru yang dibentuk seefisien mungkin. Diantaranya memberdayakan guru dengan kualifikasi S1 mata pelajaran seperti guru matematika, IPA, Bahasa Indonesia, Pendidikan Agama, Guru Muatan Lokal dari 
Lingkungan SDIT Ar-Ridho. Setiap guru telah mengatur jdwal mengajar tidak mengganggu proses belajar di SDIT Ar-Ridho. Adapun sarana gedung telah memiliki 3 lantai dengan fasilitas tiap lantai memiliki 4 ruang yang cukup besar dapat menampung tiap kelas 35 siswa. Memiliki fasilitas ruang computer. Untuk fasilitas computer ini bergabung penggunaannya dengan siswa SDIT Ar-Ridho. Di mana siswa SD setiap jam pelajaran akan ke lingkungan SMPIT Ar-Ridho untuk belajar computer. Sekolah ini berada terpisah lebih kurang 50 Meter dari SDIT Ar-ridho. Sebetulnya dibangunnya sekolah ini adalah untuk melanjutkan siswa belajar SDIT ArRidho tetap dilingkungan nuansa islami yaitu SMPIT Ar-Ridho. Memiliki fasilitas perpustakaan, dan ruang yang mushola serta kantor.

Visi sekolah ini tetap melanjutkan visi yang dibawa dari SDIT Ar-Ridho yaitu Berakhlak mulia, terampil dan cerdas. Konsep yang dibangun sekolah adalah Boarding School. Akan tetapi mengingat jumlah siswa yang masih sedikit jumlah siswa laki-laki hanya 7 siswa, maka kegiatan boarding school belum terealisasikan. Sehingga sekolah telah menyiapkan fasilitas menginap bagi siswa meliputi ruang tidur dan lemari pakaian siswa khusus siswa laki-laki saja. Konsep boarding untuk para siswa perempuan belum dapat dilaksanakan mengingat peraturan melarang dalam 1 lingkungan gedung siswa laki-laki dan perempuan bertemu dan tidak dibatasi dengan pembatas ruang. Sehingga itu sebabnya boarding hanya diperuntukkan bagi siswa lakilaki saja. ( Hasil wawancara dengan Kepala Sekolah, 15 Desember 2016).

\section{b. Hasil Penelitian}

Pelaksanaan program merupakan implementasi dari perencanaan kegiatankegiatan yang telah dilakukan. Program kepala sekolah yang dilaksanakan di SMPIT ArRidho Kecamatan Kalidoni Kotmadya Palembang yang bertujuan menarik minat calon peserta didik terdiri dari dua jenis kegiatan yaitu kegiatan tidak langsung dan kegiatan secara langsung (tatap muka). Berikut penjelasan masing-masing dari kedua jenis kegiatan tersebut.

\section{1) Kegiatan tidak langsung}

Kegiatan Kepala Sekolah tidak langsung yang dilaksanakan bersama segenap guru dalam kepanitiaan PPDB. Sosialisasi terbagi ke dalam dua jenis yaitu menggunakan media cetak dan sosialisasi dan tidak menggunakan media elektronik seperti radio atau televisi lokal. Media cetak terdiri dari brosur, dan spanduk. Brosur disebarkan setelah siswa SD melaksanakan UN. Penyebaran brosur terutama diberikan pada seluruh siswa kelas 6 SDIT Ar-Ridho bersama 
dengan aplikasi pendaftaran. Brosur tidak diberikan kepada semua siswa SD, terutama hanya pada siswa kelas 6 dan wali siswa yang bertanya saja. Berdasarkan pengamatan yang telah dilakukan peneliti, isi pesan yang disampaikan dalam brosur meliputi tentang visi dan misi sekolah, program tahfizh, fasilitas, informasi penerimaan siswa baru, dan persyaratan pendaftaran. Spanduk biasanya mulai dipasang sejak akhir Mei sampai dengan akhir Juli dengan lokasi dua sampai empat titik. Dibutuhkan pemasangan spanduk ini diharapkan sekolah banyak dikenal keberadaannya di lingkungan masyarakat. Pemasangan spanduk dengan beberapa titik seperti di daerah sekitar kenten, daerah kalidoni dan lingkungan sekolah SMPIT ArRidho.

\section{2) Kegiatan langsung}

Kegiatan tidak langsung merupakan kegiatan tatap muka atau melakukan

sosialisasi langsung menggunakan bantuan media atau tidak. Beberapa kegiatan

tatap muka yang dilaksanakan SMPIT ArRidho adalah hanya melaksanakan sosialisasi ke sekolah Mambaul Hidayah yang dilaksanakan oleh beberapa guru yang kebetulan menjadi pengawas silang Ujian Nasional. Kemudian mensosialisasikan langsung kepada siswa kelas 6 SDIT Ar-Ridho melalui pembelajaran les tambahan di lingkungan SMPIT Ar-Ridho Kegiatan ini dimulai tahun pertama penerimaan siswa baru.

Strategi yang dilakukan oleh kepala sekolah untuk menarik minat siswa adalah dengan memberikan potongan harga sampai dengan 50\%. Adapun nilai pendaftaran siswa baru adalah Rp. 4000.000,-. Dengan potongan senilai $50 \%$ maka siswa hanya membayar Rp. 2000.000,- akan memperoleh pakaian seragama sebanyak 4 pakaian seragam, yang terdiri dari 1 stel pakaian Putih Biru lengkap dengan atribut, 1 stel pakaian Olah raga, 1 stel pakaian Pramuka dengan topi (untuk siswa laki-laki) dan jilbab (untuk siswa perempuan), serta 1 stel pakaian Batik Hijau. Tidak terkecuali pula sudah termasuk pembayaran SPP 1 bulan.

Jika diteliti penawaran yang dilakukan oleh pihak sekolah sangat besar dan meringankan sekali bagi para orang tua, tetapi mengapa masyarakat belum tergerak untuk mengajak anak-anak mereka ke sekolah SMPIT Ar-Ridho, terutama alumni dari SDIT Ar-Ridho sendiri. Mereka justru lebih cenderung mencoba anaknya masuk ke sekolah negeri yang terdekat yaitu SMPN 29 dan SMPN 8. Sekolah SDIT Ar-Ridho memang bekerja sama juga dengan sekolah lanjutan negeri yang menjadi rayonnya yaitu SMPN 29 dan SMPN 8, sehingga orang tua ingin mencoba anak-anak mereka untuk tes masuk sekolah negeri. 
Strategi kepala sekolah juga dalam menarik minat siswa adalah bekerja sama dengan yayasan mengadakan beberapa kegiatan yang mengundang masyarakat. Seperti melaksanakan zikir akbar dengan mengundang penceramah luar seperti Bpk. Ustazh H. Solihin Hasibuan. Brosur dibagikan kepada setiap undangan yang hadir. Kemudian kepada Ibu Yayasan yang selalu melakukan ceramah setiap hari ke masjid dan tempattempat resmi lainnya menitipkan brosur untuk dibagikan ke para jamaah. Dan membagikan brosur kepada setiap guru SDIT Ar-Ridho untuk diberikan kepada pada keluarga, kerabat dan tetangga dekat. Kegiatan ini lebih dianggap efektif karena mereka langsung mendapat informasi secara lengkap.

Mengapa hasil PPDB yang diperoleh sangat jauh dari harapan selama 2 tahun padahal seharusnya dengn fasilitas seperti SMPIT ArRidho sangatlah mungkin mendapat siswa yang banyak.

Berdasarkan hasil wawancara dengan beberapa orang tua yang anaknya bersekolah di SDIT Ar-Ridho maka penulis mengambil kesimpulan bahwa mereka belum berminat mengajak anak-anak mereka ke SMPIT Ar-Ridho dengan alasan:

1. Anak mengalami kebosanan karena jam belajar yang sangat lama

2. Kurangnya sarana olahraga

3. Kurang menariknya program unggulan yang ditawarkan.
4. Guru-guru yang masih belum sesuai dengan kompetensinya (guru dari SDIT AR-RIDHO).

5. Anak-anak ingin masuk ke sekolah lanjutan negeri saja dengan jam belajar yang umum.

6. Kurangnya pendekatan antara pihak sekolah dengan para orang tua atau masyarakat.

7. Status sekolah yang masih baru dan harus menginduk ke sekolah yang terdekat

8. Kurang pedulinya pihak Yayasan terhadap keberadaan orang tua.

9. Kurangnya fasilitas kantin sekolah.

10. Minimnya dukungan dari pihak yayasan untuk program sekolah itu sendiri.

Lebih jauh penulis melihat permasalahan juga menyangkut keterbatasan biaya dan tenaga yang dibenarkan oleh Ibu Meriana Pane (Kepala sekolah 2015-2016) merupakan hasil wawancara pada tanggal 16 Desember 2016 yang mengatakan bahwa selain faktor siswa, permasalahan lain adalah mengenai keterbatasan biaya dan kurangnya tenaga muda yang menyebabkaa "jemput bola" yang dilakukan kurang intens. Di samping itu hasil dari pengamatan peneliti pada studi pendahuluan maka kendala yang ditemukan antara lain adalah biaya promosi yang sangat minim dan para orang tua yang kurang mengetahui program kegiatan yang tawarkan sekolah seperti program tahfizh, olahraga, dan seni SMPIT Ar-Ridho Kalidoni Palembang. Dari beberapa pemaparan di atas dapat dianalisis bahwa kendala yang menyebabkan strategi kepala sekolah dapat terlaksana secara 
maksimal karena terdapat pada dua faktor utama yaitu faktor dari luar dan factor dari dalam (sekolah). Faktor dari luar terkait dengan masalah keengganan calon peserta didik untuk sekolah di sekolah yang baru dengan status belum terakreditasi dan harus menginduk ke sekolah terdekaat. Faktor teman dari calon peserta didik yang kuat mempengaruhi kelanjutan sekolah, faktor orang tua yang tidak mengetahui program unggulan sekolah dan faktor dari keinginan siswa yang ingin bersekolah negeri. Kurangnya dalam menyediakan waktu untuk pelaksanaan sosialisasi. Sementara faktor dari dalam (sekolah) menyangkut faktor sumber daya sekolah seperti keterbatasan tenaga pelaksana dan finansial.

\section{Evaluasi dan Tindak Lanjut}

Evaluasi managemen strategi kepala sekolah dilaksanakan pada setiap akhir program PPDB. Sebelum evaluasi, selama pelaksanaan program diadakan monitoring yang dilakukan langsung oleh kepala sekolah sebagai penanggung jawab kepada panitianya setiap seminggu sekali, hal ini diungkapkan oleh Ibu Meriana Pane, S.Ag. Monitoring yang dilakukan untuk mengetahui hasil jumlah peserta didik sementara yang didapatkan, pada kuantitas atau jumlah siswa yang didapat dalam kurun waktu tertentu. Disimpulkan bahwa kegiatan monitoring yang dilakukan untuk mengetahui progress kegiatan sehingga ketika terdapat beberapa kendala dapat dilakukan langkah perbaikan saat itu juga.

Sementara evaluasi program dilakukan pada setiap program PPDB usai dalam rapat atau yang disebut dengan rapat penutupan PPDB. Adapun yang mengevaluasi adalah para panitia kegiatan termasuk di dalamnya kepala sekolah, guru dan seluruh staff. Harus kita tingkatkan untuk mendapatkan siswa, kelemahankelemahan seperti kurang intens dalam pendekatan selama "jemput bola". Mengevaluasi kelemahan-kelemahan dari kepanitiaan sendiri, mengidentifikasi kesan yang kurang melakukan pendekatan di mata masyarakat tentang sekolah.

Dari pendapat di atas maka dapat ditarik kesimpulan bahwa beberapa aspek yang dievaluasi adalah bersifat menyeluruh yang artinya semua hasil kerja dievaluasi seperti perolehan hasil jumlah peserta didik yang disesuaikan dengan target, kelemahan baik dari panitianya, metode atau cara dalam kegiatan menarik minat calon peserta didik, maupun dari sekolahnya sendiri. Meskipun telah dilakukan evaluasi setiap akhir PPDB mengenai keseluruhan permasalahan yang ada, bentuk tindak lanjut belum terlaksana, hal ini disebabkan keterbatasan biaya.

Dari wawancara penulis dengan kepala sekolah, diketahui bahwa masalah utama yang menghambat dilakukannya tindak lanjut 
adalah masalah keterbatasan biaya yang dimiliki sekolah sedangkan kebutuhan vital dari internal sekolah seperti beban gaji guru yang juga masih belum tercukupi dengan baik. Belum maksimalnya tindak lanjut tersebut telah berdampak pada hasil PPDB dalam dua tahun berjalan.

\section{KESIMPULAN}

Berdasarkan hasil penelitian dan pembahasan yang telah dipaparkan di atas, maka dapat ditarik kesimpulan bahwa manajemen strategis kepala sekolah dalam PPDB yang dilakukan oleh Kepala Sekolah, guru dan semua karyawan, aspek yang direncanakan meliputi jenis kegiatan, pembentukan panitia, sasaran program, sasaran tempat, penjadwalan atau waktu, anggaran dan isi pesan yang disampaikan. Penunjukan panitia berdasarkan domisili guru, kemampuan, kekuatan fisik dan loyalitas. Sasaran program adalah semua lulusan dari berbagai sekolah terdekat dalam range kecamatan kalidoni dan siswa SDIT Ar-Ridho khususnya. Jenis kegiatan yang direncanakan meliputi publikasi melalui spanduk, brosur, dan beberapa kegiatan tatap muka seperti sosialisasi ke SD terdekat, kerjasama dengan guru, kerjasama dengan masyarakat, orang tua dan Ibu Yayasan kegiatan "jemput bola". Pemetaan lokasi kegiatan berdasarkan factor potensial, strategis dan memanfaatkan daerah setempat. Dana berasal dari sisa-sisa kegiatan sekolah dan tidak ada anggaran khusus dalam memperkirakan pengeluaran kegiatan.

Pelaksanaan program humas terdiri dari dua jenis yaitu kegiatan yang bersifat tidak langsung (menggunakan media cetak) dan kegiatan bersifat langsung atau tatap muka. Pelaksanaan program diawali dengan penyebaran brosur yang dilaksanakan oleh seluruh warga sekolah. Kemudian diikuti dengan sosialisasi ke MI Mambaul Hidayah, kerjasama dengan guru secara serentak. Pemasangan spanduk dilakukan saat menjelang pelaksanaan PPDB antara akhir Mei sampai dengan bulan Juni. Sementara kegiatan "jemput bola" dilaksanakan sejak sebelum PPDB, saat pelaksanaan PPDB berlangsung hingga bulan September batas sekolah swasta menerima peserta didik.

Kendala program antara lain berasal dari dua faktor yaitu faktor dari luar dan faktor dari dalam sekolah. Faktor dari luar mencakup faktor calon peserta didik sendiri, pembangunan sekolah-sekolah baru yang berdampak pada persaingan ketat, sebagian orang tua yang tidak mengetahui program sekolah sedangkan faktor dari dalam berasal dari terbatasnya tenaga guru dan karyawan dan sumber daya finansial mengakibatkan minimnya kegiatan yang dilaksanakan. Sejauh ini belum ada tindak lanjut atas permasalahan penerimaan siswa baru tersebut. 


\section{DAFTAR PUSTAKA}

Ahmadi, Abu dan Uhbiyati, Nur. (2001). Ilmu Pendidikan. Jakarta: PT Rineka Cipta.

Aly, Hery Noer. (1999). Ilmu Pendidikan Islam. Jakarta: Logos.

Arikunto, Suharmini. (1992). Metodologi Penelitian Kuantitatif. Jakarta: Rineka Cipta.

David, Fred R (2004). Manajemen strategi konsep-konsep (Edisi Kesembilan). PT. Indeks Kelompok Gramedia. ISBN 979683-700-5

Fattah, Nanang. (2009). Landasan Manajemen Pendidikan. Bandung PT. Remaja Rosdakarya.

Kristiawan, M. Safitri, D. Rena L. (2017). Manajemen Pendidikan. Yogyakarta: Deepublish.
Moleong, Lexy J. (2005). Metodologi Penelitian Kualitatif. Bandung: Remaja Rosdakarya

Siagian, P. Sondang. (2000). Manajemen Stratejik. Jakarta: Bumi Aksara.

Sagala, Syaiful. (2010). Supervisi Pembelajaran. Bandung: Alfabetha.

Suharto, Toto. (2006). Fissafat Pendidikan Islam. Jogjakarta: Ar-Ruzz.

Usman, Husaini dan Akbar, Purnomo Setiadi. (1996). Metodologi Penelitian Sosial. Jakarta: Bumi Aksara.

Wahyudi, Agustinus Sri. (1996). Manajemen Strategik Pengantar Proses Berfikir Strategik. Jakarta: Binarupa Aksara 